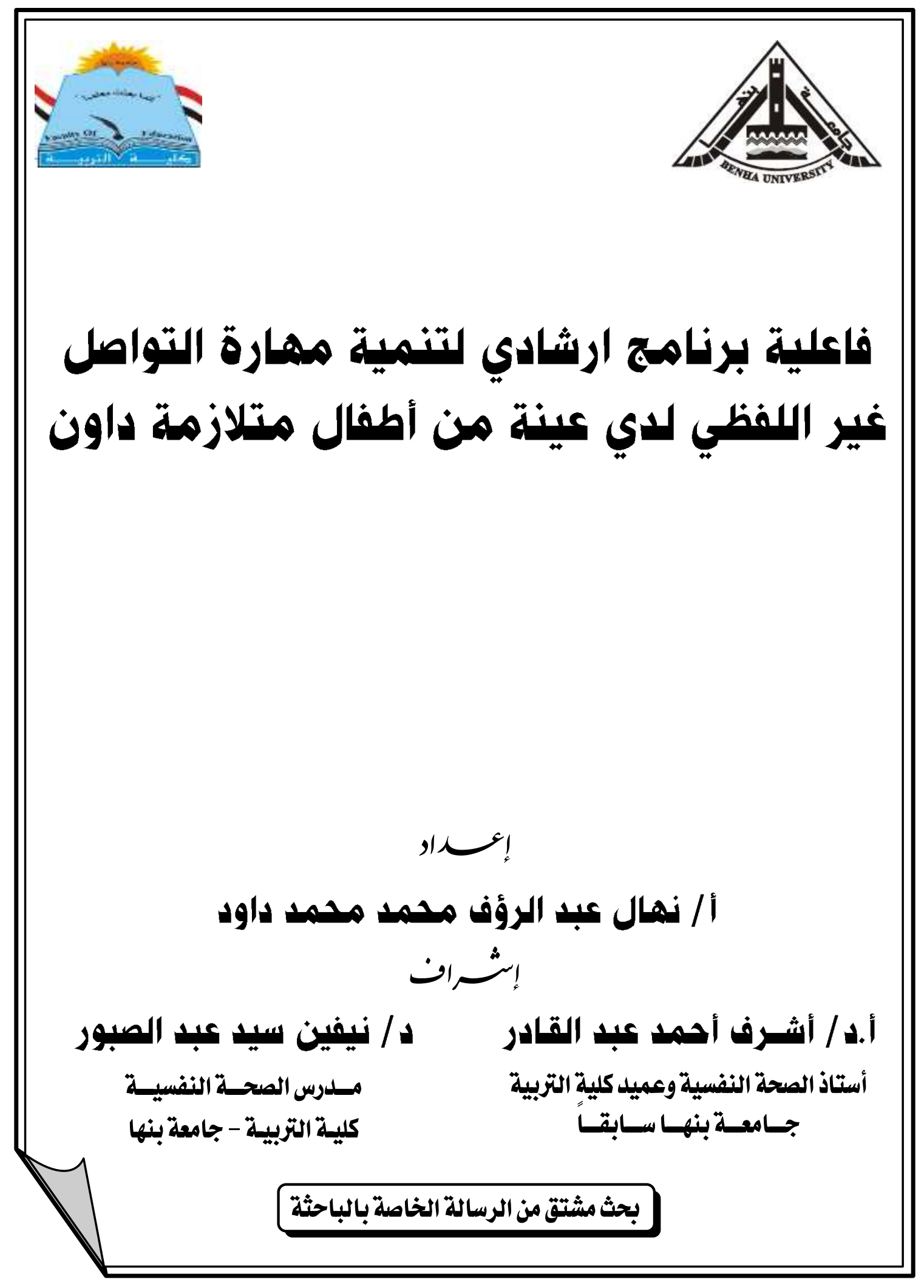




\title{
فاعلية برنامج ارشادي لتنمية مهارة التواصل غير اللفظي لدي كينة من أطفال متلازمة داون
}

\author{
! إن
}

أ / نهال وبد الرؤف محمد محمد داود<smiles>[AlH][CH][AlH]</smiles>

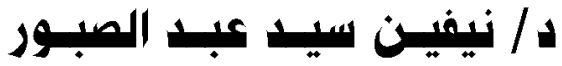 \\ مسلدرس الصحسة النفسيـة \\ كلية التربية - جامعة بنها}

أ. ده / أشسرف أحمد عبد القهادر

أستاذ الصحة النفسية وعميدكلية التربية

جسامعـة بنهـاسابقـا

\section{المستخلص}

هدفت الدراسة الحالية إلي معرفة مدي فاعلية برنامج إرشادي في تتمية مهارة التواصل

غير اللفظي لدي عينة من أطفال متلازمة داون، وقد اشتملت عينة الدراسة علي ه أطفال من ذوي متلازمـة داون، تراوحت اعمارهم بين (-0) سنوات، وقد قامت الباحثة بتطبيق استمارة مقابلة شصية علي الأمهات، كما قامت بتطبيق مقياس التواصل غير اللفظي علي الأطفال بمساعدة الأمهات، قبل وبعد تطبيق البرنامج، وكانت نتائج الدراسة حدوث تحسن ملحوظ في مهارات التواصل غير اللفظي لدي أفراد العينة أطفال متلازمة داون. 
أ نهال داود، أ. د/ أشرف أحمد، د/ نيفين سيد فاعلية برنامج إشادي لتنهية مهارة التواصل غير اللفظي لدي عينة من أطفال متلاز زمة داون

\section{Abstract}

The present study aimed to determine the effectiveness of a pilot program in non-verbal communication skill development in a sample of children with Down syndrome, was the study sample included five children with Down syndrome, ages ranged from 5-7 years, and the researcher application form interview hookworm on mothers, and has implemented a non-verbal communication scale for children with the help of mothers, before and after the application of the program, and the results were a marked improvement in non-verbal communication skills, I have a sample of children with Down syndrome. 


\section{أولاً: الــافـع الـى الـدراسـة:}

تعتبر فئة الإعاقة العقلية واحدة من فئات التربية الخاصة الأكثر شيوعا مقارنة بالفئات الأخرى، كالسمعية والبصرية والحركية واللغوية، وأكثرها شيوعاً؛ حيث تُعد الإعاقة العقلية ظاهرة

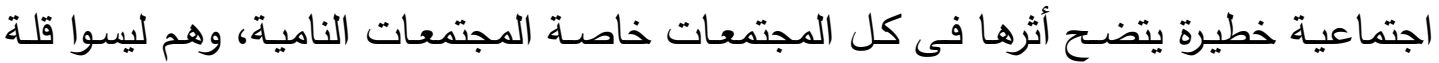
يمكن تجاهلها، فثمة 7 - V \% من الأطفال فى مرحلة ما قبل المدرسة ينتمون لهذه الفئة، فهم ليسوا عديمى الفائدة كما يتصور البعض ولكنهم بحاجة إلى خدمات خاصـة. (جمال الخطيب

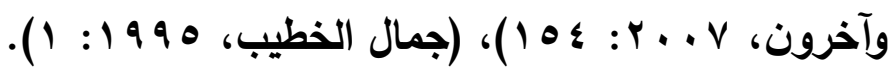

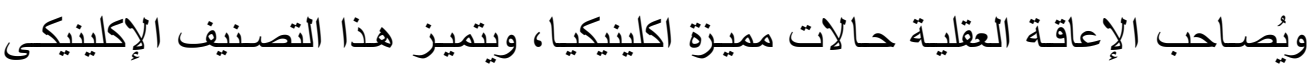
بإمكانية التعرف على بعض الحالات فى التخلف العقلى من خلال المظهر العام، حيث اعتمد هذا التصنيف على وجود خصائص جسية تشريحية فسيولوجية إضافة إلى عامل الذكاء، ومن هذه الأنماط الإكلينيكة حالات المنغولية (متلازمـة داون)، والتي يمكن التعرف علي أفرادها

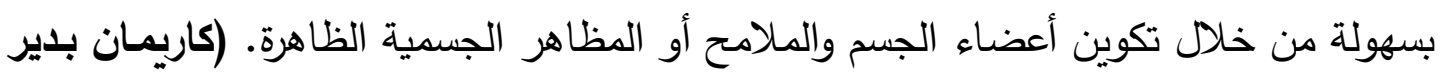

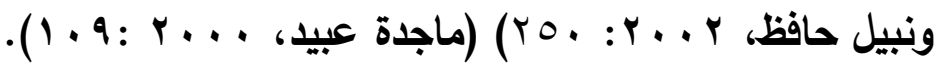

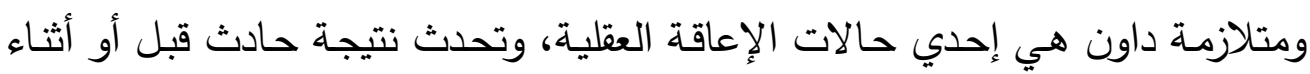

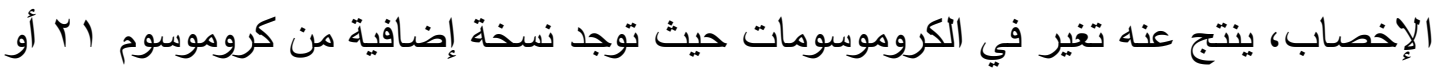

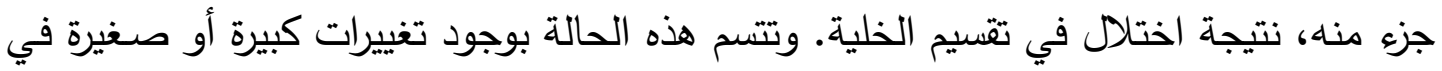

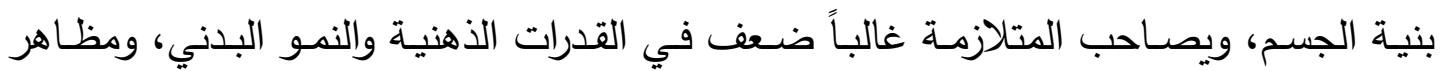

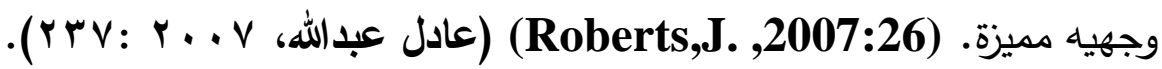
وممـا سبق يتضـح أن أطفـال متلازمـة داون يعانون مـن قصـوراً واضـحاً في مهارات التواصل بصفة عامـة؛ ويرجع ذلك إلي أن أطفال متلازمة داون لديهم صفات دات جسمية مميزة، تختلف عن فئات الاعاقة العقلية الأخرى.

\section{ثانياً: مشكالسة الـدراسـلة:}

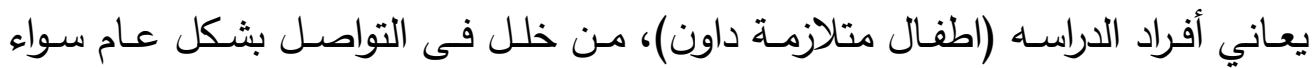
(خاصة غير اللفظى)، حيث انهم يتميزون ببعض المظاهر الجسدية، والملامسح الوجهية المميزه

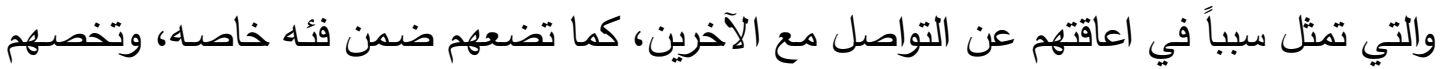
دون غيرهم من الأطفال العاديين او الأطفال المعاقين عقليا من غير ذوى متلازمة داون. 
وهذا مـا دفع الباحثة لإعداد برنـامج إرشادي، يستهدف تنمية مهارات التواصل غير اللفظي لدي أطفال متلازمة داون. ولقد تبلورت المشكلة في ذهن الباحثة من خلال عمل الباحثة بإحدي مراكز ذوي الاحتياجـات الخاصـة، والتقائهـا بأطفال هذه الفئة، وكذا مـن خـلال نتائج الدراسات السابقة، التي اظهرت تطوراً واضحاً في بعض مهارات التواصل لدي المعاقين عقلياً وأطفال متلازمـة داون، عن طريق برامج التدخل المبكر ، حول إعداد برنـامج تدرببي للتدخل المبكر ، يهدف إلي تتمية مهارات التواصل اللفظي وغير اللفظي لأطفال متلازمة داون؛ وتبلورت مشكلة الدراسة في التساؤل التالي: • مـا فاعليـة برنـامج التدخل المبكر فـى تنميـة بعض مهارات التواصل "اللفظى وغير اللفظى" لاى عينه من الأطفال المصابين بمتلازمة داون؟

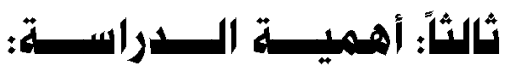

تكمن أهمية الدراسة الحالية، في أنها تقع ضمن نطاق اهتمامات الدولة بذوي الاحتياجات الخاصـة، والحث علي ضـرورة وضـع الخطط والاستراتيجيات والبرامج التي تسهم في الحـد مـن الإعاقة، أو الحد من آثارها السلبية علي الفرد والمجتمع ككل؛ والعمل علي تكيفهم مع الاشخاص المحيطين بهم، والمجتمع الذي يعيشون فيه، وفقاً لقدرات وإمكانات كل منهج؛ هذا بالإضـافة إلي إلقائها الضوء علي فئة من فئات ذوي الاحتياجات الخاصـة، والتي تحتاج المزيد من التدخل، ألا وهي أفراد متلازمـة داون، كمـا أنها تسهم في التصدي لأهم المشكلات التي يواجهها أفراد هذه الفئة، وهـي ضـف القدرة علي التوافق مـع الآخر ، نظراً لأنهـ يعـانون مـن مشكلات واضـحة وقصور شديد في مهارات التواصل غير اللفظي، ونظراً لأن أفراد هذه الفئة يندرجوا تحت قائمسة المعـاقين عقلياً القابلين للتعلم، فهم لديهم القدرة علي التعلم؛ ولكن بطرق واستراتيجات وبرامج خاصـة تناسب قدراتهم وامكاناتهم. ومن هنـا تأتى أهميـة الدراسـة والتى تكمن فى ضـرورة تقديم برنامج إرشادي لأفراد العينه (أطفال متلازمة داون) لتتمية مهارات التواصل غير اللفظي لديهم.

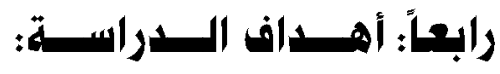 \\ تهذف الاراسد الحاليه إلى:}

التعرف علي مدي فاعلية برنامج إرشادي لأطفال متلازمـة داون لتتمية بعض مهارات

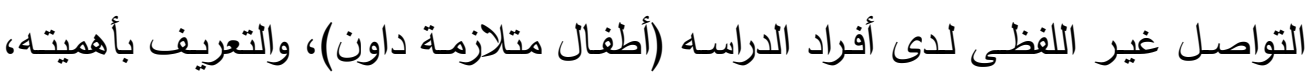
ومدى فاعليته. 


\section{خامساً: مصطلدـات الـدراسـة:}

\section{متلازمة داون: Down's Syndrome}

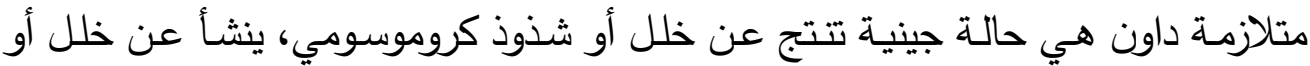

شذوذ في أنقسام الخلايا، سواء قبل الحمل أو بعد حدوثه، وسواء كانت الخلايا أنثوية أو ذكرية، مما يؤدي إلي وجود كروموسوم إضـافي للكروموسوم رقم (Y) علي أثر ذلك، وبالتالي يصبح ثلاثياً

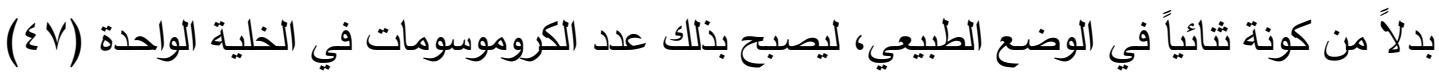

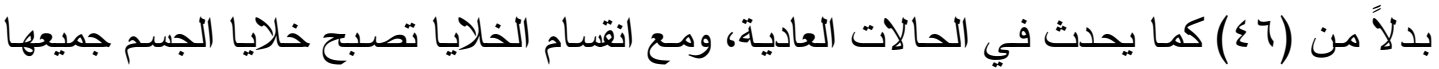

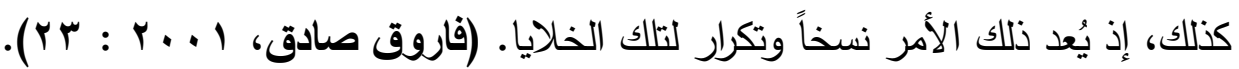

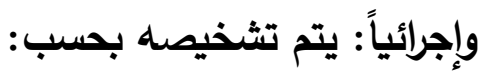

• الملامح الوجهية المميزة، والصفات الجسمية المشتركة لأفراد متلازمة داون.

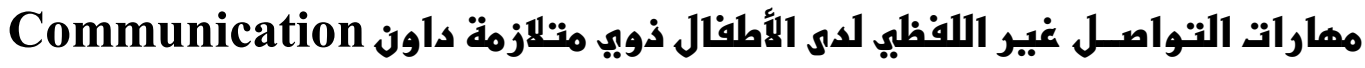 with down cyndrom children}

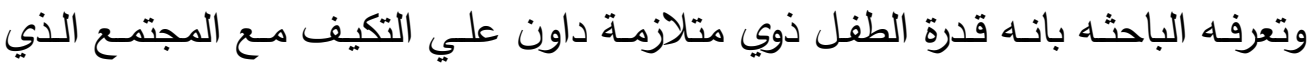

يعيش فيه عن طريق القدره علي التعامل مع افراده من خلال فهم الاوامر والتعليمات التي توجها لـه بصوره غير لفظيه والقدره علي تتفيذها، وكذلك القدره علي توجيه الرساله للطرف الآخر بطريقه غير لفظيه وبالتالي يتمكن الطفل ذوي متلازمة داون من الحصول علي مطالبه التي يرغب فيها؛ وهي مجموعة من السلوكيات غير اللفظية والتي تصدر عن طفل الداون فى سنين عمره الأولى سواء من داخل اسرته او من خلال احتكاكه بالعالم الخارجى ككل، فالجانب غير

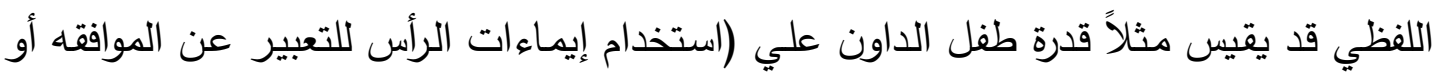

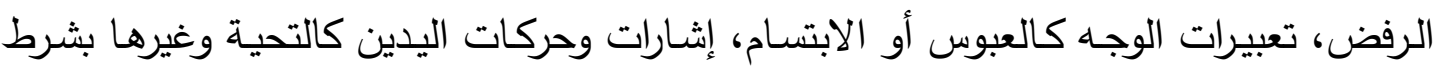

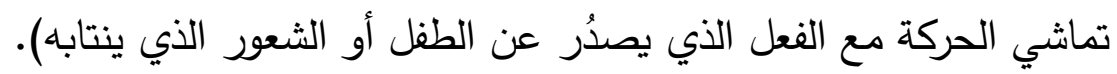

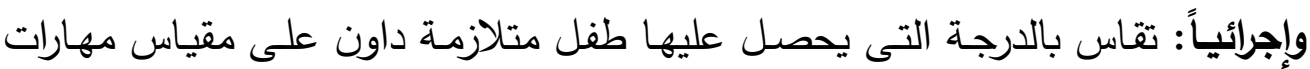
التواصل غير اللفظي، إعداد الباحثة.

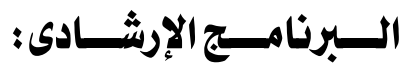

هو عبارة عن برنامج مخطط منظم فى ضوء أسس علمية، لتقديم الخدمات الارشادية المباشرة وغير المباشرة، فردياً وجماعياً، لجميع من تضمهم المؤسسة (مركز للتربية الخاصـة

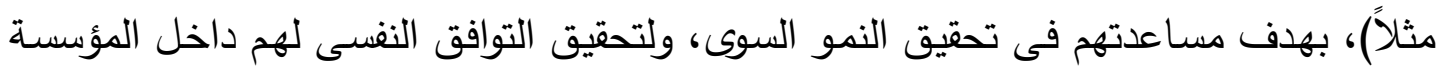

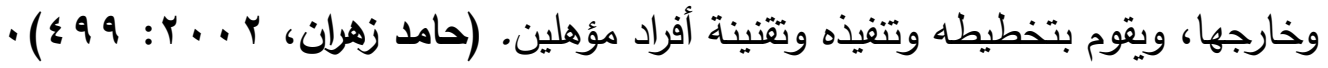


وإجرائياً: هو البرنامج الإرشادي الذي قامت الباحثة بإعداده، والذي تضمن عدة فنيات هي:

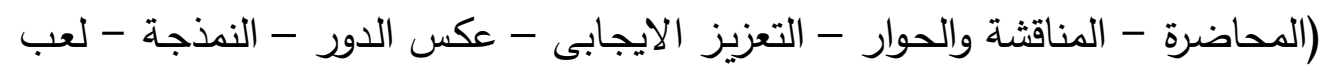

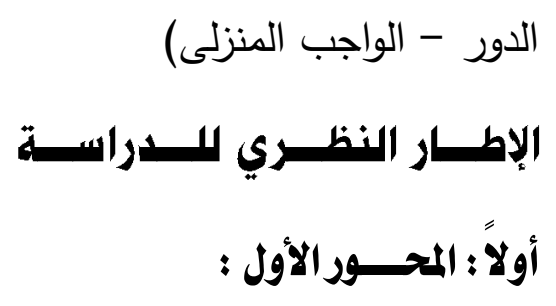

\section{متلازمة داون Down Syndrome أو زملة أعراض داون Down's Syndrome}

متلازمة داون هى تلك المشكلة النمائية التى حيرت وما زالت تحير العلماء والباحثين،

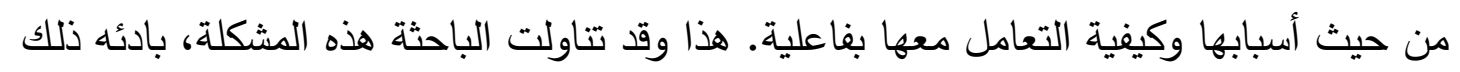

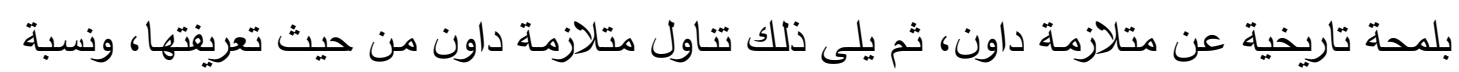
انتشارها، وأسبابها، وخصائص أفرادها.

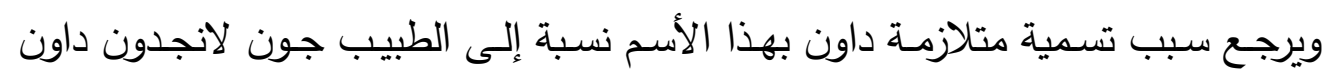

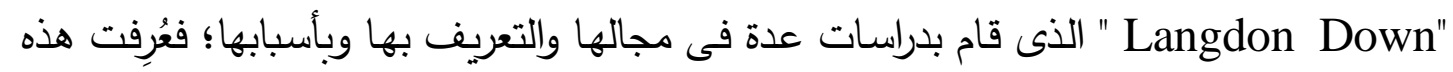
الحالة بإسم مكتشفها، وأُطلق عليها هذا الاسم بعد أن كانت تسمي بالمنغولية نسبة إلى التشابه بين الملامح العامة لأفراد هذه الفئة وأفراد الجنس المنغولى. وقد بقيت مثل هذه التهدي التسمية للأطفال

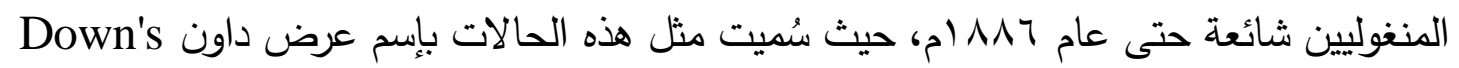
بعد هذا العام. وجدير بالذكر أن منغوليا قدمت شكوى إلى الأمم المتحدة بهذا دئا

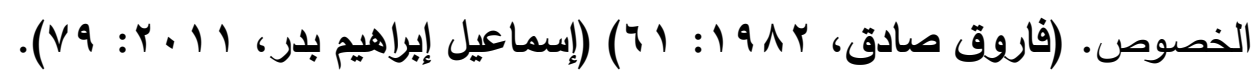

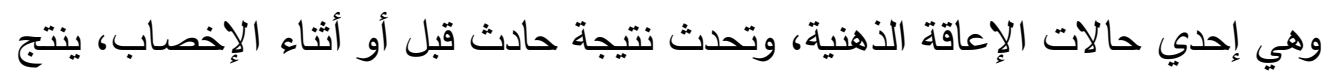

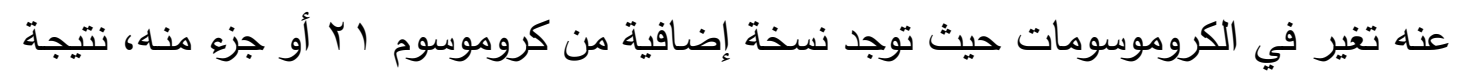

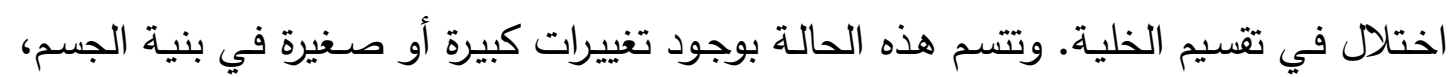
ويصاحب المتلازمـة غالباً ضعف في القدرات الذهنية والنمو البدني، ومظاهر وجهيه مميزة.

(Roberts, J., 2007: 26).

وتستخلص الباحثة مما سبق تعريفاً لمتلازمة داون يتمثل في: "متلازمة داون شكل من

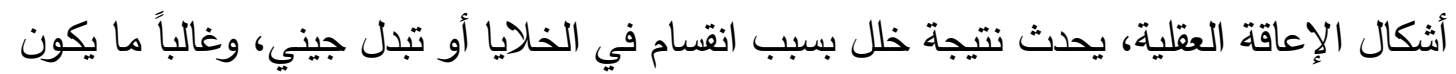
مصحوباً بضعف في القدرات الذهنية، والبدنية، كما يكون مصحوباً بمظاهر وجهيه مميزة". 
ويتم تثخيص طفل متلازمة داون مبكراً بعد الولادة بناءً على ملامسح وجهية وسمات جسمية على الطفل، ومن أهم الملامح والسمات ما يلى : ه إرتخاء عام فى عضلات الجسم والمفاصل وضعفها، وقد تتحسن حالة الطفل كلما كبر . يكون وزن الطفل وطوله أقل من المعدل عند الولادة. العينان صغيرتان مائلتان نحو الأعلى، مع وجود تثقق فى الجفون.

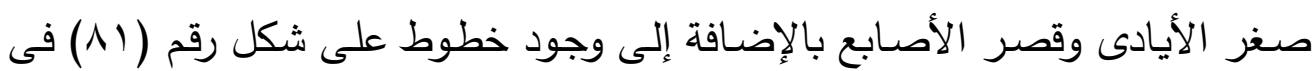
راحة اليد اليمنى، و(1) (1) فى راحة اليد اليسرى [عكس الإنسان السليح]. الرقبة قصيرة، والثعر ناعم ومستقيم. معظم أطفال متلازمة داون قصار القامة، ممتلئو الجسم. "الرأس مستدير ، صغير الحجم نسبياً، وجبهته عريضة، ويُلاحظ تفلطح مؤخرة الرأس. هوجد مسافة كبيرة نسبياً بين إصبعى الرجل (الإبهام والسبابة).

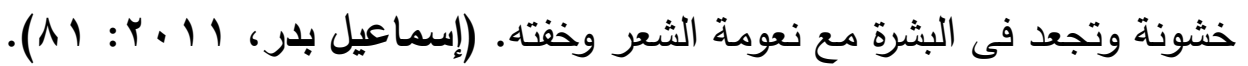
وتشير معظم الدراسات أن وجدان أطفال الداون يتسم بالقصور Muted إذا قورن بوجدان الأطفال غير التخلفين من نفس العمر العقلى فمثلاً، يبتسم طفل الداون للمنبهات التى تثتئير الضحك من جانب الأطفال العاديين أو يعبس Whimpers فى المواقف التى يبكى فيها الطفل العادى بكاء شديداً. وسرعان ما تتعود أمهات الداون على مستويات الإثارة المنخفضة لإى أطفالهن

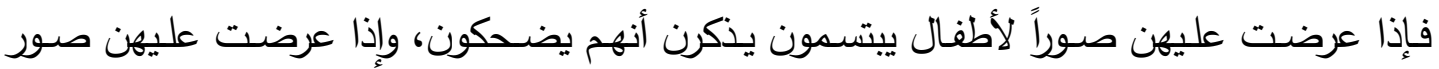
لأطفال عابسى الوجوه يذكرن أنهم يبكون. وقد يرتبط هذا المستوى المنخفض للإثارة بإنخفاض قوة لإن إناض

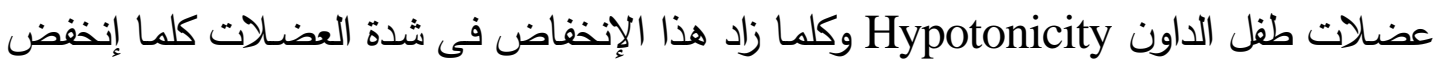

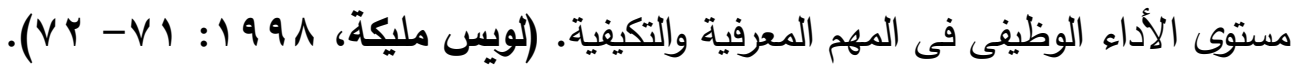

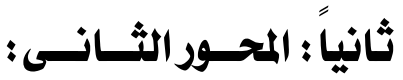

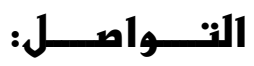

إن التواصل هو الفطرة التي فطرنـا الله سبحانه وتعالي عليها، فالإنسان بطبعه كائن

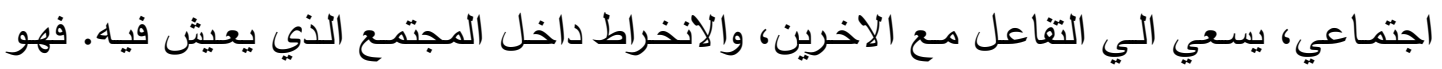
ينجذب للجماعة، ويجد نفسة في الاندماج داخلها، واجتماعية الانسان هذه، هي التي تدفعسه للعيش تحت سقف الجماعة، فنجده يُفضل الخضوع لقوانين الجماعة، علي حرية العيش بمفرده 
خارج لوائها. ولا يتحقق له الوصول إلي أهدافه هذه إلا من خلال التواصل، سواء كان لفظياً عن

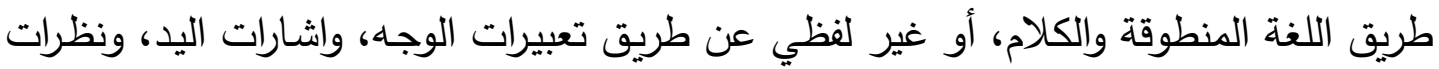
العين، ووضعيات الجسم المختلفة.

فالتواصل فى جوهره هو عملية نقل المعانى عن طريق الرموز المتعارف عليها، وعن طريق التواصل يدخل الافراد فى علاقات اجتماعية مع بعضهم البعض أو مع بيئاتهم الخاصة.

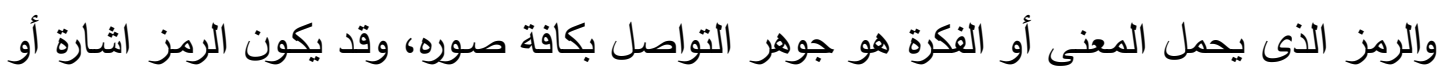

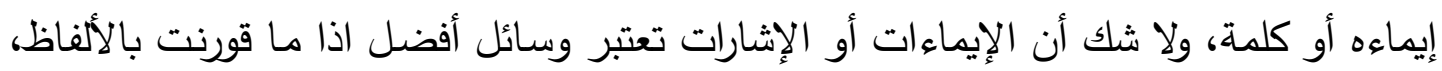
ولكنها قد تأتى مصاحبة للتعبير اللغوى.

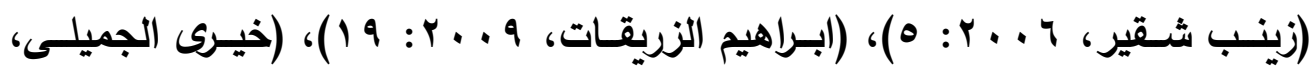

$$
.(£ \wedge-\leqslant \vee: 199 \vee
$$

وتعرف الباحثة التقاصل بأنه عملية نقل رسالة من مرسل إلى مستثبل، والرسالة مدكن أن

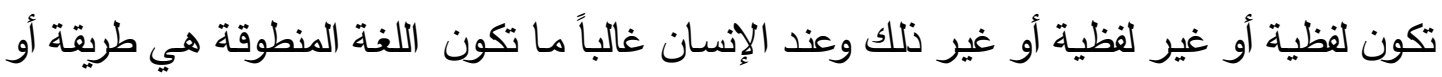
أسلوب لتبادل المعلومات بين الأفراد، بينما تكون لغة الجسد هي أسهل طريقة لفهم وتوصيل المعلومة.

\section{ثالثاً : برامج إرشاد ذوى متلازمة داون:}

والبرنـامج ارشادي هو عبارة عن برنـامج مخطط منظم فـى ضـوء أسس علميـة، لتقديم

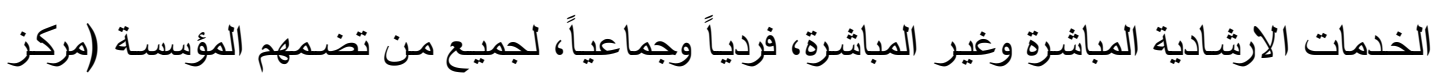
للتربية الخاصة مثلاً)، بهدف مساعدتهم فى تحقيق النمو السوى، ولتحقيق التوافق النفسى لهم داخل

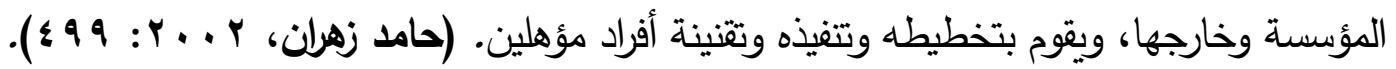

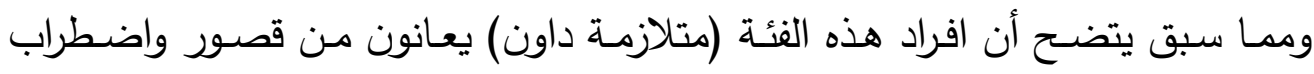

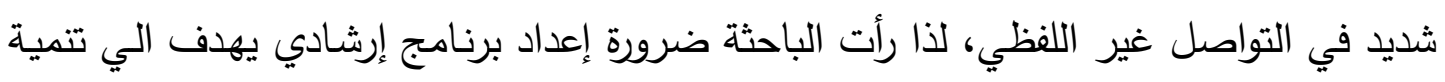
بعض مهارات التواصل غير اللفظي لدي أفراد هذه الفئة.

\section{السدراسـات الســابة}

دراسة أكسيو لي وانج، وأخرون (Xiao-lei Wang, et al, 2001) وهدفت

إلي معرفة أثر تقديم المعلمين للدعم اللفظي وغير اللفظي علي الأداء الدراسي لطلابهم ذوي متلازمة داون. 
وقد تم تطبيقها على عينة الدراسة والتى تكونت من: · عمدرس و • ؛ طالب أعمارهم (Vنوات) من ذوى متلازمة داون؛ حيث تم وضع الطلاب المشاركون تحت الملاحظة، ويجري تسجيل فيديو لأنشطتهم الروتينية داخل فصولهم، أمـا المدرسون فيجري تقسيمهم إلي ثلاث مجموعات، لأختبار الوسائل التدعيمية المتبعة. حيث قامت المجموعة الأولي من المدرسين بإستخدام التدعيم بالتخاطب فقط، بينما استخدمت المجموعة الثانية، وسيلة التدعيم التي جمعت بين التخاطب والاشارة، أما الثالثة، فقد استخدمت وسيلة التدعيم بالاشارة فقط. وقد كان من نتائج هذه الدراسة، أن الطلاب كانوا أكثر فهماً، واستيعاباً لمدرسيهم، الذين اسـخدموا الوسـائل التدعيميـة التي تتضـمن الإشـارة، سـواء كانـت الاشـارة وحدها، أو الاشـارة والتخاطب معاً.

دراسة (محمد السعيل عبد الجـواد أحمـل أبـو حلاوة، r+•r) وهدفت إلى معرفة مدى إسهام برنـامج إرشـادى فى تتميـة مهارات التواصـل الاجتمـاعى لدى عينـة من الأطفال المعوقين القابلين للتعلم. اختيرت عينـة من · ع طفلا وطفلة من ذوى الإعاقة العقلية القابلين للتعلم من ذوى الإقامة

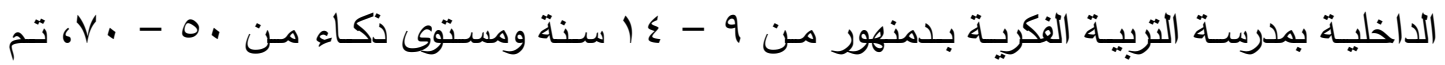
توزيعهم بشكل عشوائى على مجموعتين (تجريبية وضابطة). واستخدم الباحث برنامج تتمية مهارات التواصل الاجتماعى للأطفال المعوقين عقليا، دليل إرشادى لآباء ومعلمى هؤلاء الأطفال، مقياس مهارات التواصـل الاجتمـاعى، مقيـاس تقدير المستوى الاجتمـاعى الاقتصـادى للأسـرة المصـرية. وتوصلت الدراسـة إلى أنـه لم يطرأ أى تحسن فى أداء أطفال المجموعة الضـابطة، فى حين حدث تحسن دال فى أداء أطفال المجموعة التجريبية على مقياس مهارات التواصل الاجتماعى فى القياس القبلى والبعدى والتتبعى. وعدم وجود تباين دال فى درجات الأطفال الذكور والإنـاث بالمجموعـة التجريبية على مقياس التواصل الاجتماعى فى القياسات الثلاثة.

\section{دراسـةجـيولونجـوبرادي وآخرون (Jana, Longobardi, et all, 2003)}

وهدت إلي التحقق من الاختلافات في العلاقة بين التواصل اللفظي وغير اللفظي وأثرها في تطور اللغـة في وقت مبكر لدي أطفال متلازمـة داون، حيث تكونت عينـة الدراسـة من عشرة أطفال مـن عائلات الطبقة المتوسطة العليا، وكان متوسط العمر الزمني (YV,T شهرا)، ومتوسط العمر العقلي

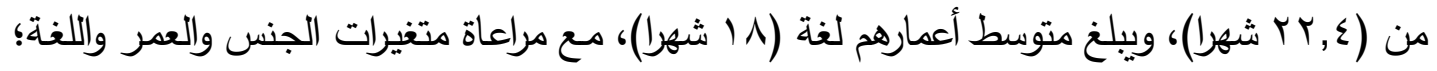

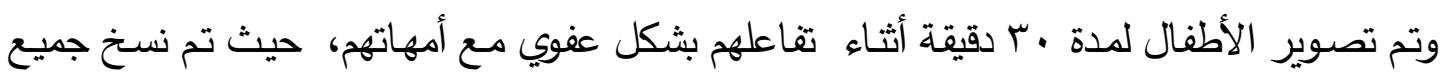
أثكال التواصل الصادرة عن هؤلاء الأطفال من إيماءات وكلمات علي أثرطة الفيديو. 


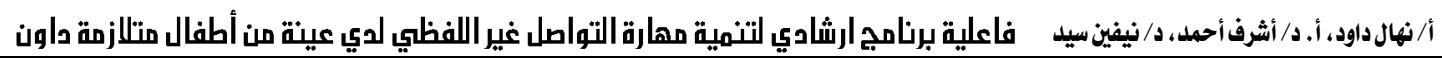

وكان من نتائج هذه الدراسـة: أن الذخيرة التواصلية (سواء اللفظية أو غير اللفظية) لأطفال متلازمة داون أقل بكثير من لغة الأقران في مثل سنهم.

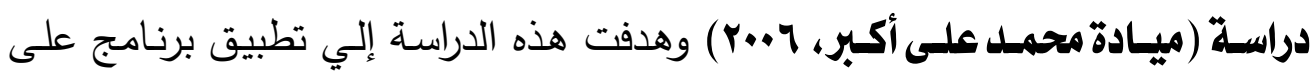

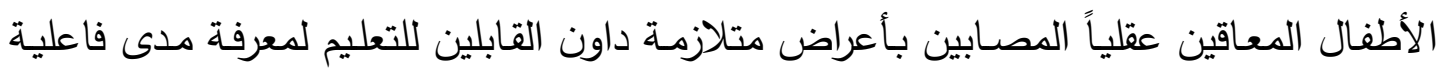

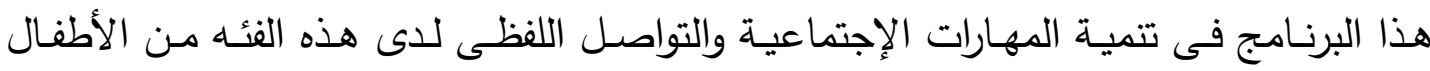
(المعاقين عقلياً المصابين بأعراض متلازمة داون القابلين للتعليم).

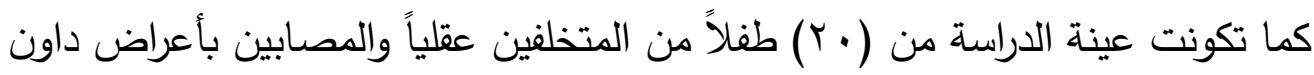
وتتراوح أعمارهم الزمنيه بين (؟- Y I ) سنة.

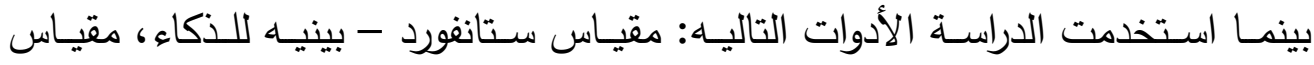

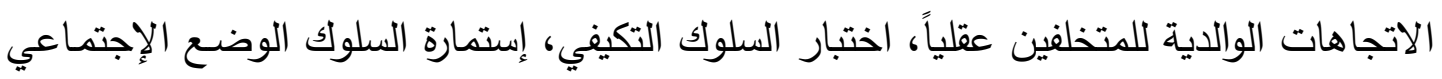
والاقتصادي للأسرة. ولقد حقق البرنـامج النتـائج المرجـوه منـهـه في تتميـة المهارات الاجتماعيـة ومهـارات

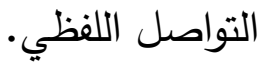

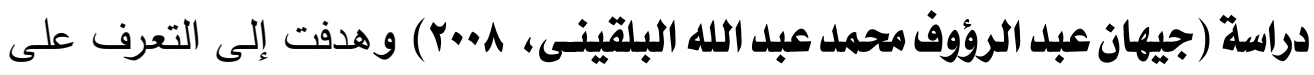

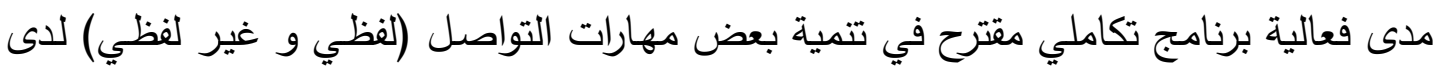
الأطفال المعاقين عقليا عينة الدراسة التجريبة. وتكونت عينة الدراسة الحالية من (ب) طفلا من الأطفال المعاقين عقليا فئة القابلين

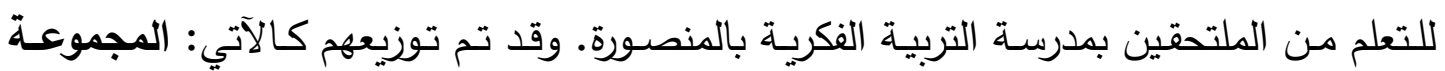

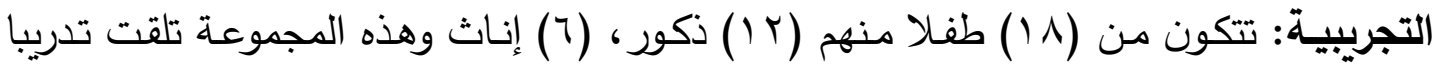

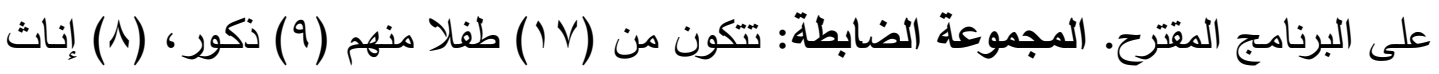
وهذه المجموعة لم تتلقى التدريب على البرنامج المقترح.

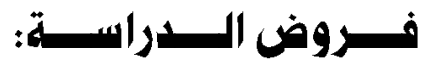

من خلال الإطار النظرى والدراسـات والبحوث السـابقة، تمكنت الباحثة من صياغة

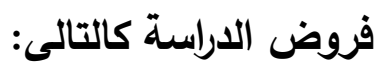
1- توجد فروق ذات دلالة إحصائية بين متوسط رتب درجات القياسين القبلي والبعدي علي

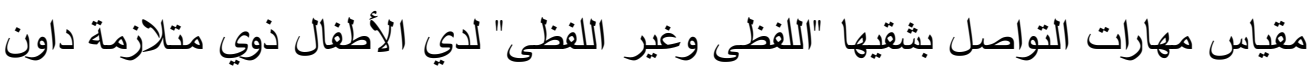
لصالح القياس البعدي. 
ץ- لا توجد فروق ذات دلالة إحصائية بين متوسط رتب درجات القياسين البعدي والتتبعي علي

مقياس مهارات التواصل بشقيها "اللفظى وغير اللفظى" لدي الأطفال ذوي متلازمة داون.

ويشمل المنهج المستخدم والخطوات الإجرائية وتحديد عينة للدراسة، وعرض لأدوات الدراسة

وطرق حساب الصدق والثبات، والأساليب الإحصائية المستخدمة للوصول إلى نتائج الدراسة.

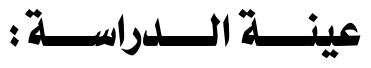

كانـت مجموعـة الدراسـة في صـورتها الأوليـة ء ا طفل وتـم استبعاد ؟ اطفـال كانـت درجاتهم مرتفعة بعد الاجابة علي أسئلة المقياس، وطفلان نظراً لعدم ملائمة ظروفهم الأسرية في المشاركة في البرنامج، وطفلان آخران كانا يعانيا من مشكلات خلقية بالقلب. وبذلك وصلت العينة إلي 7 أطفال، ثم تم استبعاد طفلاً منهم لم يكمل جلسات البرنامج، وبذلك وصلت العينـة في صورتها النهائية إلى ه أطفال وأمهاتهم انخفضت درجاتهم عن المتوسط بصورة ملحوظة

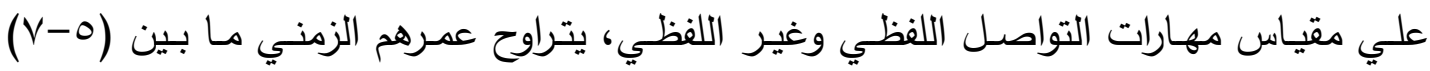
سنوات تم تشخيصهم كحالات أطفال ذوي متلازمة داون.

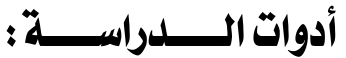

الأداة الأولى: استمارة جمع ببانـات لأمهات الأطفال ذوي متلازمة داون:

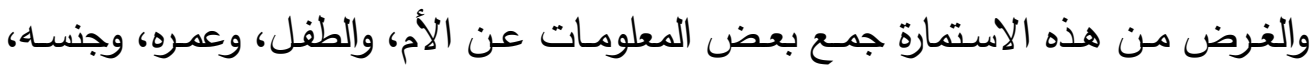
وأسرته، وغير ذلك. ويتم تطبيق هذه القائمة على (الأم) حيث تُعد هي القائمة علي رعاية الطفل.

\section{الأداة الثانبة: مقياسر التواصل الفظظي و غبـر الافظلي لدي أطفال متلازمة داون (صورة}

\section{الوالدهن) (إعداد/الباهنثة):}

لإعداد الصورة الأولية للمقياس اتبعت الباحثة الخطوات التالية:

1-مراجعة الإطار النظري والدراسات السابقة الخاصـة بمهارات التواصل اللفظي وغير اللفظي

والإستفادة منها في بناء المقياس وتحديد أبعاده وتحديد التعريفات الإجرائية للأبعاد.

r - الإطلاع علي أهم المقاييس الخاصـة بمهارات التواصل اللفظي وغير اللفظي - وبناءاً

علي ذلك، وفي ضوء الإطلار النظري والدراسـات السـابقة، إنتهت الباحثة إلي تحديد أبعاد وعبارات مقياس التواصل اللفظي وغير اللفظي لدي أطفال متلازمـة داون، والتي تمركز حولها أكبر نسبة إتفاق 


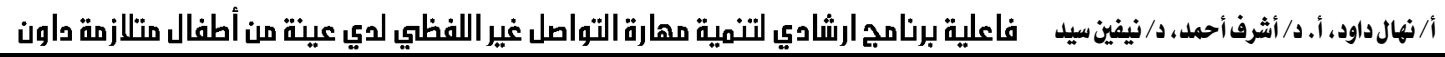

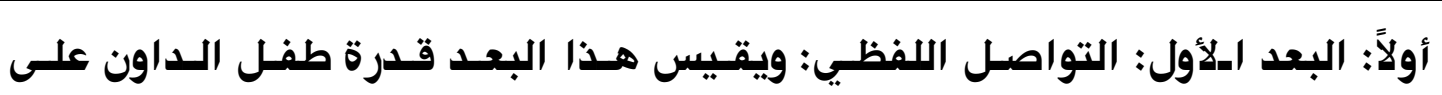
استخدام اللغتة اللفظيتة واستيعابها:

فهـذا البُعـد يقيس قدرة طفـل الـداون على المنـاداة وقدرتــة علـي استعمال الأوامـر

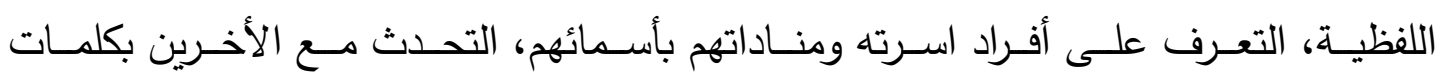

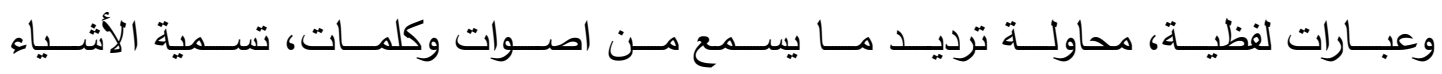

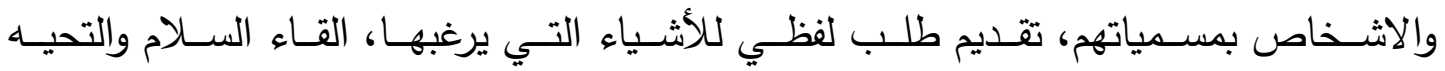
بالقول، معرفة عبارات الثكر والاعتذار .

ثانياً: البعد الثاني: القدرة على استخدام لغتة الجسد وتوظيفها بشكل مناسب: ويقيس هذا البُعد قدرة طفل الداون على استخدام حركات اليد، إيماءات الرأس مثل

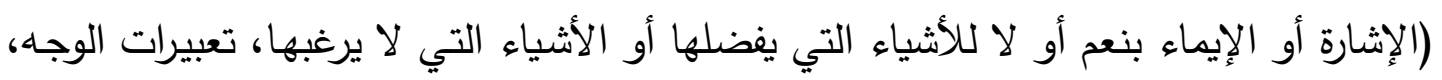

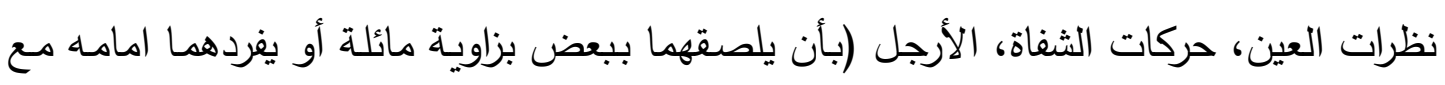

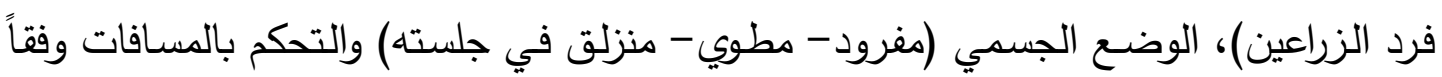

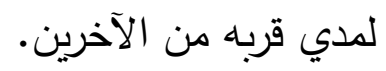
ثم قامت الباحثة بحساب الخصائص السيكومترية للبطاقة بعدة طرق: مســاب صــــ المقيـــاسر:

الصدق الظاهري Face Validity:

أن أحد مؤشرات الصدق هو الصدق الظاهري وهو أن يكون الاختبار في مظهره يشير إلى أنه صادق ويعني عرضه على مجموعة من المتخصصين والخبراء في المجال الذي يقيسه الاختبار على أن هذا الاختبار يقيس السلوك المراد قياسه.

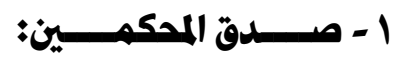

بِناءً على نسبة الاتفاق بين المحكمين وعددهم بَ لكل عبارة من عبارات البطاقة تم

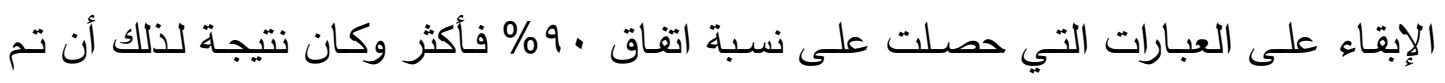
الإبقاء على جميع العبارات التي تضمنتها البطاقة دون حذف أو تعديل بخلاف تعديل بسيط في الصياغة والتي لا يؤثر تغييرها في معني العبارة. 
أولاً: صدق الأبعاد بطريقتة الارتباط الثنائي هع المحك الداخلي جلول (r) صدق الأبعاد بطريقة الارتباط الثنائي مع المحك الداخلي

\begin{tabular}{|c|c|c|}
\hline الثـــــي & الأول & الأبعـــــاد \\
\hline •, $१ \leqslant १$ & •, १ะ१ & معامل الارتباط \\
\hline$\cdot, \cdot 1$ & $\cdot, \cdot 1$ & الدلالة الإحصائية \\
\hline
\end{tabular}

يتضح من الجدول السابق أن قيمة معاملات الإرتباط والتي تظهر بقيمة 9 ؟ 9 . ، وهي قيمة قريبة من الواحد الصحيح مما يعني ان المقياس دال إحصـائياً عند مستوى" ا .,. " "، مما يدل على أن المقياس يتمتع بدرجة عالية من الصدق. هسباب تبــات المقبـاسر: قامت الباحثة بحساب ثبات المقياس بطريقتين هما: • طريقة التجزئة النصفية طريقة كرونباخ للاتساق الداخلي وذلك على النحو التالي:

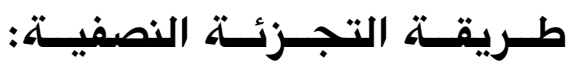
جلول معاملات الثبات بطريقة التجزئة النصفية ودلالاتها الإحصائية

\begin{tabular}{|c|c|}
\hline معاملات الثبات ودلالاتها الإحصائية & معـــادلــة حســـاب معــامـل الثبـــات \\
\hline ,,977 & معادلة سبيرمان وبراوذ \\
\hline •,955 & معادلة رولون \\
\hline .,923 & معادلة جتمان \\
\hline & 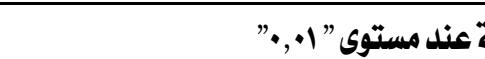 \\
\hline
\end{tabular}

ويتضـح من الجدول السـابق أن قيم معاملات الثبات المحسوبة من المعادلات الثلاث دالة إحصائياً عند مستوى" ا +, · "، مما يدل على أن المقياس يتمتع بدرجة عالية من الثبات. طريقتة كرونباخ للاتساق الداخلي:

\begin{tabular}{|c|c|}
\hline \multicolumn{2}{|c|}{ Reliability Statistics } \\
\hline \hline Cronbach's Alpha & Cronbach's Alpha Based on Standardized Items \\
\hline 0.926 & 0.926 \\
\hline \multicolumn{2}{|c|}{} \\
\hline \hline
\end{tabular}




\section{تصصب.}

$$
\text { جاءت مفردات المقياس على قياس ثلاثي متدرج (دائماً- أحياناًَ- أبداً). }
$$

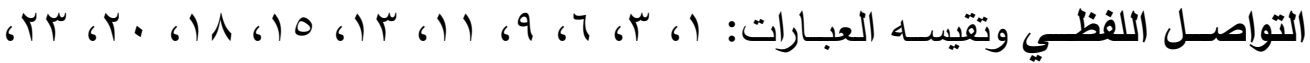

rO

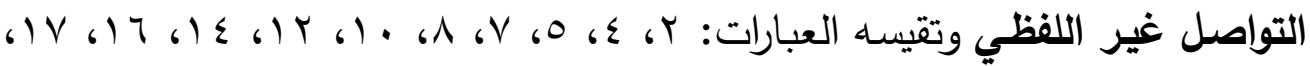

Y

وبناءً عليه تكون أعلي درجة علي المقياس (•^1أم) وأقل درجة (بr)

\section{البـرنامـة الإرشسادي (إعداد/الباحثة): \\ 1- التعريف بالبرنامج الإرشادي:}

البرنامج الإرشادي المستخدم في هذه الدراسة قائم علي إستراتيجية الإرشاد وذلك لتتمية

مهارات التواصل غير اللفظي وينعكس ذلك إيجابيا علي حالة طفل متلازمة داون من ناحية القدرة علي التواصل.

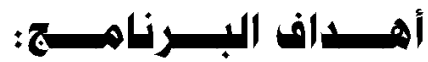

يتحدد الهدف العام للبرنامج في محاولة تتمية مهارات التواصل سواء غير اللفظيه للدي الأطفال ذوي متلازمة داون من خلال برنامج إرشادي؛ ومن ثم الإستفاده منهم كعضو فاعل في المجتمع من خلال توظيف قدراتهم لخدمته بدلاً من أن يصبحوا عبئًا ثقيلاً عليه.

\section{مصـادر اشتقــاق محتــوي الــبرنامسـج :}

اعتمدت الباحثه فى بناء محتوى البرنامج التدربيى على مصادر عديدة، وهى: ا- الإطار النظرى للدراسـة الحالية، والذى يلقى الضوء على مشاكل التواصل لدى الطفل ذو متلازمة داون وكيفية علاجها، وذلك عن طريق التدخل المبكر مع طفل الداون بالتدريب

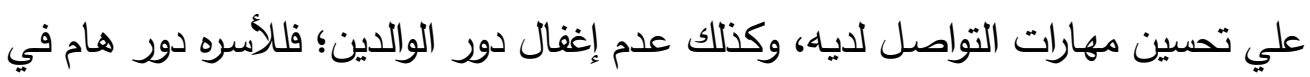
تحسين مهارات التواصل لدي طفلهم ذو متلازمة داون - خاصـة في برامج التدخل المبكر حيث أنها النواه الأولي التي ينشأ فيها الطفل، ومجتمعه الصغير والأكثر إحتكاكاً به. r- الاطـلاع على بعض الدراسـات والبحـوث السـابقة_ العربيـة والأجنبيـة_ التى تتاولت بـرامج التدخل المبكر مـع الطفل ذو متلازمة داون، والإستقادة منها فى إعداد البرنامج الحالى، وقد إعتمدت بعض هذه البرامج علي الوالدين كركيزه أساسيه، وكذلك الدراسات التي تتاولت تدريب الطفل ذو متلازمـة داون لتحسين مهارات التواصل لليه، وكذلك الدراسـات التى تتاولت أثر إستخدام برامج التخخل المبكر في تتمية مهارات التواصل لدي أطفال متلازمة داون. 
ץ- عمل الباحثة في وقت سابق بإحدي مراكز ذوي الاحتياجات الخاصـة والتي كانت تضم

أطفالاً من ذوي متلازمة داون، مما ساعد الباحثة في التعرف بصورة أكبر علي هؤلاء

الأطفال، وعلي خصائصهم، وكيفية التعامل معهم، وجوانب القصور التي يعانون منها؛

$$
\text { الأمر الذي ساعد الباحثة في إعداد هذا البرنامج. }
$$

\section{خطة الجلسات التنفيذية للبرنامج التلدريبي}

وأوجزتها الباحثة في الجدول التالي والذي إشتمل علي مراحل البرنامج والهدف من كل

$$
\text { مرحلة، وعدد جلسات كل مرحلة. }
$$

\begin{tabular}{|c|c|c|c|c|}
\hline الفنيــــات المستخــــــــة & زالجنة & الهــــــــــف من الجلســــــة & عنــــــوان الجلســـــة & | لجلسة \\
\hline المحاضرةوالمناقشة الجماعية & 高 & 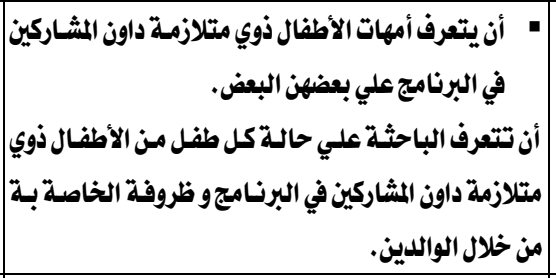 & التعارف بالأمهات & b: \\
\hline المحاضرة والمناقشة الجماعية & 腺 & 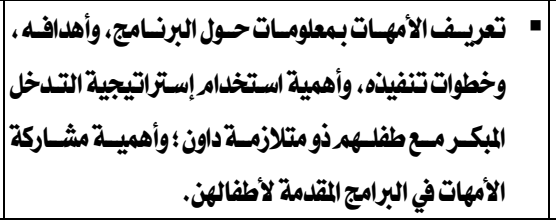 & تعريف الأمهات بالبرنامج & 事 \\
\hline الجماعية_التعزيز_التعله & 旁 & 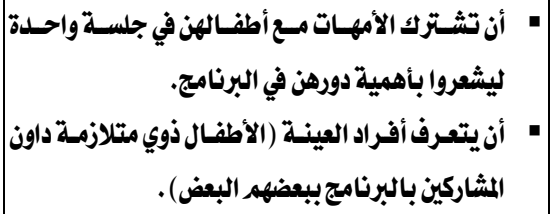 & التعارف بين الباحثة وأفراد العينة. & 鸦 \\
\hline التعله باللعب_التعزيز & 总 & 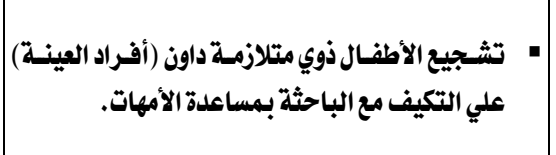 & تهيئة الأطفال للبرنامج & $\overline{3}$ \\
\hline التعلد باللعب_التعزيز & 离 & 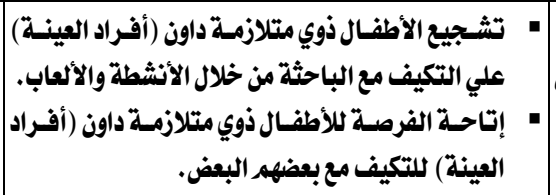 & إلبرنامجال الجلسة السـابقة(تهيئة الأطفال & 雨 \\
\hline التعلم باللعب_التعزيز & 禜 & 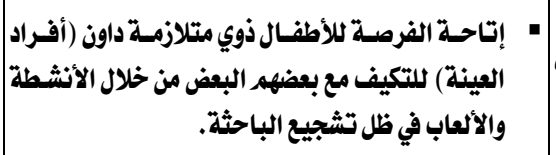 & إلبرنامجال الجلسة السـابقة(تهيئة الأطفـال & $\overline{3}$ \\
\hline
\end{tabular}

\section{مخطط جلسات برنامج تحسين مهارات التواصل لدي أطفال متلازمة داوز}


أ / نهال داود، أ. د/ أشرف أحمد، د/ نيفين سيد فاعلية برنامجارشادي لتنهية مهارة التواصل غير اللفظي لدي عينة من أطفال متلازمة داون

\begin{tabular}{|c|c|c|c|c|}
\hline الفنيــــات المستخـــمــة & زالجلة & الهــــــــــف من الجلســـــة & عنــــــوان الجلســــة & | رقمة \\
\hline النفذجة_لعب_الدور_عكس الدوري & 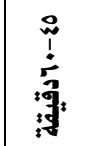 & - - أن يتــدرب الطفـل ذو متلازمـة داون أمسام المـرآة علـي & | التعرف علي ملامح الوجة & 㨞. \\
\hline النمذجة_لعب_الدور_عكس الدور & 总 & 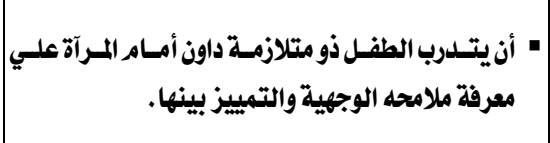 & |إسـتكمال الجلســة السـابقة التعـرف علـي| & 牙 \\
\hline النمذجة_لعب_الدور_عكس الدور & 离 & - - أن يتــدرب الطفـل ذو متلازمسة داون أمساه المـرآة علـي & 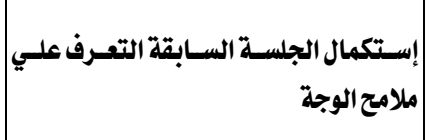 & 哥 \\
\hline النمذجة_لعب_الدور_عكس الدور & 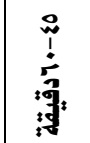 & - أن يتدرب الطفل ذو متلازمة داون علي الإبتسام. & | الإبتساه والعبوس. & 牙 \\
\hline النمذجة_لعب_الدور_عكس الدور & 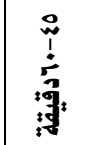 & - أن يتلدرب الطفل ذو متلازمة داون علي العبوس. & | إستكمال الجلسة السابقة (الإبتسام والعبوس). & 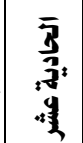 \\
\hline 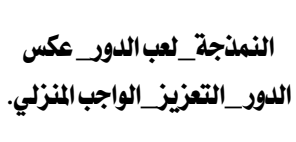 & 总 & - - أن يميـز الطفـل ذو متلازمـة داون علـي بـين الإبتسـاه & | إستكمال الجلسة السابقة (الإبتساه والعبوس). & 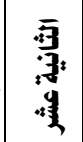 \\
\hline 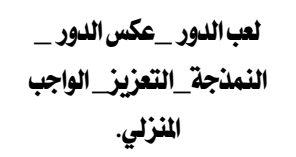 & 竞 & - - أن يتدرب الطفل ذو متلازمة داون علي كيفية التواصل & | التواصل الوجهي. & 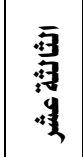 \\
\hline النمذجة_الدور_عكس_الدور_التعزيز_المواجب & 竞 & - أن يتدرب الطفل ذو متلازمة داون علي كيفية التواصل & | إستكمال الجلسة السابقة (التواصل الوجهي). | & 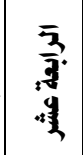 \\
\hline 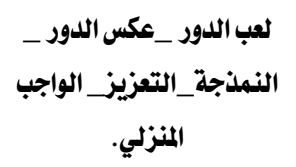 & 蕰 & - ألم يميـز الطفل ذو متلازمـة داون بـين تعبيرات الوجـة & | إستكمال الجلسة السابقة التواصل الوجهي. & 凫 \\
\hline 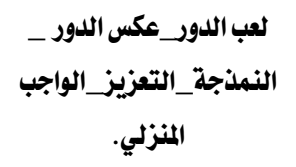 & 旁 & | - أن يتدرب الطفل ذو متلازمة داوذ علي كيفية التواصل & 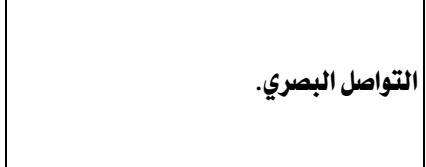 & $\frac{3}{3}$ \\
\hline
\end{tabular}




\begin{tabular}{|c|c|c|c|c|}
\hline الفنيــــات المستخـــــــة & زالجلسة & الهــــــــــف من الجلســـــة & عنــــــوان الجلســـــة & |الجلسة \\
\hline لعب الدور_عكس الدور _ النمذجة_التعزيز_الواجب & 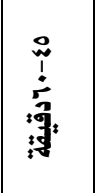 & - أن البـدرب الطفل ذو متلازمة داون علدي كيفية التواصل & إستكمال الجلسة السابقة التواصل البصري. & 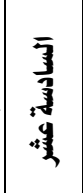 \\
\hline لعب الدور_عكس الدور _ النمذجة_التعزيز_الواجب & 品 & - أن البـدرب الطفل ذو متلازمة داون علي كيفية التواصل & إستكمال الجلسة السابقة (التواصل البصري). & $\begin{array}{l}\overline{3} \\
\overline{3} \\
3 \\
3 \\
3\end{array}$ \\
\hline النمذجة_لعب_الدور_عكس الدور_التعزيز_الواجب & 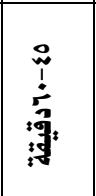 & - - أن يتـلدرب الطفـل ذو متلازمــة داون علـي التعبير عـن & التواصل الجسدي & 产 \\
\hline النمذجة_لعب الدور_عكس الدور_التعزيز_الواجب & 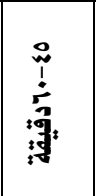 & - - أن يتـلدرب الطفـل ذو متلازمــة داون علـي التعبير عـن & إستكمال الجلسة السابقة (التواصل الجسلي). & 可 \\
\hline النمذجة_لعب_الدور_عكس الدور_التعزيز_الواجب & 离 & - أن يستطيع الطفل ذو متلازمة داون التمييز بـين معاني & إســكمال الجلســة الســابقة (التواصـل & 可 \\
\hline التعلم باللعب_النملجة__لعب & 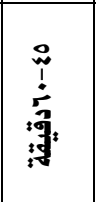 & - - أن يتــلـرب الطفـل ذو متلازمسـة داون علـي اسـتخداه & التواصل بحركات اليلين. & $\begin{array}{l}\overline{9} \\
.3 \\
.3\end{array}$ \\
\hline التعلد باللعب_النمدجة_لعب التعزيز_الواجب المنزلي. & 草 & | - أن يستخلدم الطفـل ذو متلازمــة داون حركـات اليـلين & بحركات اليلين). & 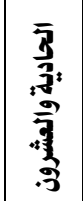 \\
\hline التعلم باللعب_النمدجة_لعب التعزيز_الواجب المنزلي. & 离 & - أن يلــدرب الطفـل ذو متلازمــة داون علـي الإسـتجابة & بحركات اليلين). & 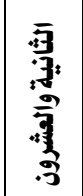 \\
\hline التعلم باللعب_النملذجة_لعب التعزيز_الواجب المنزلي. & 离 & 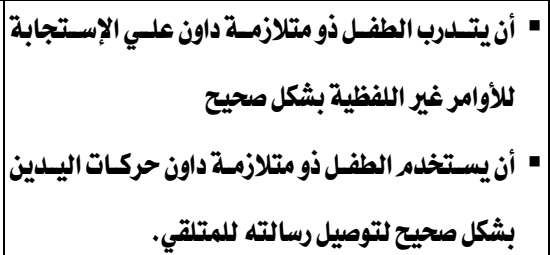 & 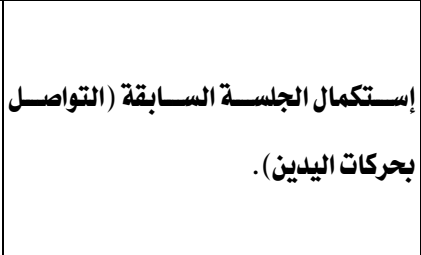 & 露 \\
\hline
\end{tabular}


أ / نهال داود، أ. د/ أشرف أحمد، د/ نيفين سيد فاعلية برنامجارشادي لتنهية مهارة التواصل غير اللفظي لدي عينة من أطفال متلازمة داون

\begin{tabular}{|c|c|c|c|c|}
\hline الفنيــــات المستخــــــــة & | الجلسة & الهـــــــــف من الجلســـــة & عنــــــوان الجلســـــة & |الجلسة \\
\hline الدور_التعزيز_الواجب_الدور_عكس & 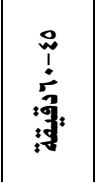 & | - أن يسـتخدم الطفـل ذو متلازمــة داون يـلـه الـيمني في & | التحية باليد & 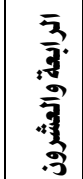 \\
\hline 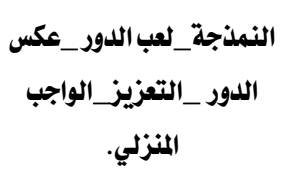 & 旁 & | - أن يستخده الطفل ذو متلازمـة داونيـلـه في مصافحة & إستكمال الجلسة السابقة ( التحية باليد). & 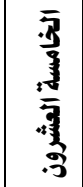 \\
\hline 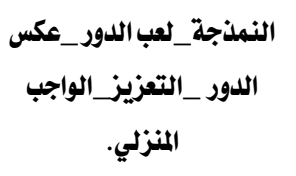 & 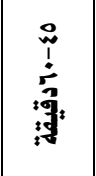 & | - أن يستخده الطفل ذو متلازمـة داون يـلـه في مصافحة | & |إستكمال الجلسة السابقة (التحية باليد). & $\begin{array}{l}3 \\
\frac{3}{3} \\
\frac{3}{3} \\
.3 \\
.3\end{array}$ \\
\hline 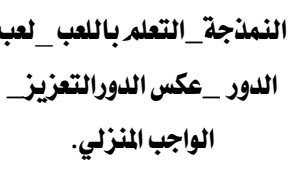 & 旁 & 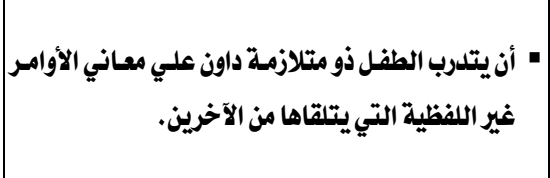 & | التفاعل مع إشارات الفير & 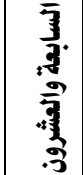 \\
\hline 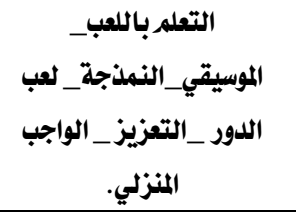 & 旁 & 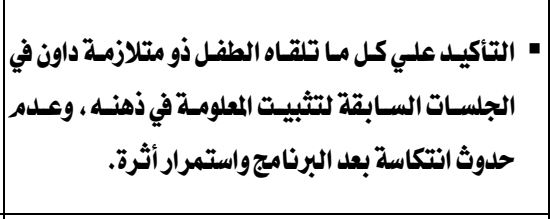 & 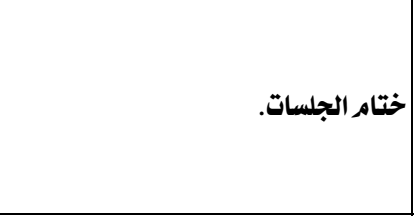 & 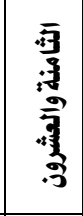 \\
\hline _الماضرة _المناقشة الجماعية الماجب المنزلي. & 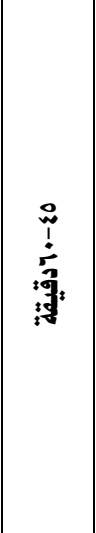 & 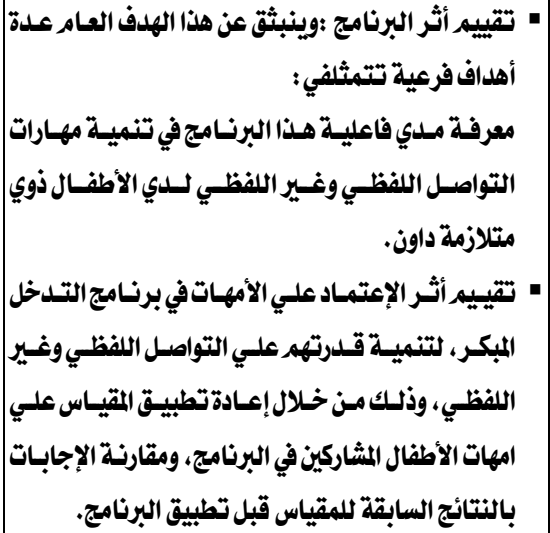 & 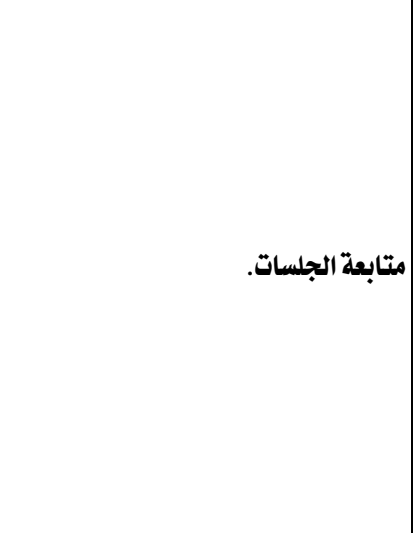 & 痌 \\
\hline
\end{tabular}

\section{:}

استعانت الباحثة بمجموعة من الأساليب الإحصائية من خلال حزمة البرامج الإحصائية

للعلوم الإجتماعية والمعروفة بـrSPSS ومن أهم الأساليب الإحصائية المستخدمة:

Wilcoxon Test الإحصاء اللابارامتري المتمثل في إختبار ويلكوكسون للدلالة الإحصائية 


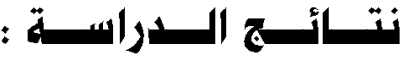

وللتوصـل إلـى نتـائج الدراسـة، التـي تثبت صـــة أو نفـي صــة فـروض الدراسـة، استخدمت الباحثة اختبـار ويلككسون للدلالــة والمبين في الفصـل الرابع - وكذلك باستخدام SPSS23 وهذا بهدف التأكيد على صحة النتائج. وكانت النتائج كالآتي:

\section{1- نتيجة الفرض الأول : (تأثير متفير البرنامج) :}

نص الفرض: توجد فروق ذات دلالة إحصائية بين درجات التطبيق القبلي والتطبيق البعدي؛ فى بعض مهارات التواصل بشقيها "اللفظى وغير اللفظى" لاي الأطفال ذوي متلازمة داون؛ بعد تطبيق البرنامج لصالح التطبيق البعدي. وللتوصل الى ذلك قامت الباحثة بحساب الفروق ودلالتها بين متوسطات رتب القياسين القبلى والبعدى لدي الأطفال ذوي متلازمة داون فى بعض مهارات التواصل، باستخدام اختبار ولككسون للدلالة الاحصائية اللابارامترية؛ وكانت النتائج كالتالى: • أن الفرق بين متوسطى رتب درجات القياسين البعدى والقبلى في الدرجة الكلية، وكذلك

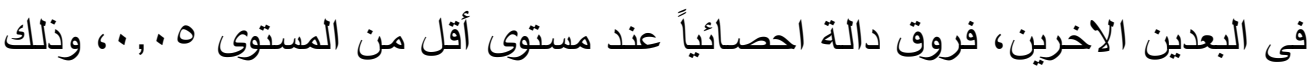
لصالح القياس البعدى، مما يؤيد صحة الفرض الأول من فروض الدراسة.

\section{r- نتيجة الفرض الثاني : (تأثير متفير البرنامج بعد فترة المتابعة) :}

نص الفرض: لا توجد فروق ذات دلاله إحصائيه في مهارات التوصل بشقيها "اللفظي وغير اللفظي" لاي أطفال متلازمة داون، في القياسين البعدي والتتبعي. وللتوصل الى ذلك قامت الباحثة بحساب الفروق ودلالتها بين متوسطات رتب القياسين البعدى والتتبعى لأطفال متلازمـة داون فى بعض مهارات التواصل اللفظي وغير اللفظي، باستخدام اختبار ولككسون للدلالة الاحصائية اللابارامترية؛ وكانت النتائج كالتالى: • أن الفرق بين متوسطى رتب درجات القياسين البعدي والتتبعي في الدرجة الكلية، وكذلك فى البعدين الاخرين، فروق غير دالة احصائياً عند مستوى أقل من المستوى هـ ـ.... س (كانت فترة المتابعة بعد شهرين من انتهاء البرنامج) 
من خـلال الأحتكاك المباشر للباحثة مـع عينـة أفراد الدراسـة الحالية، لكست الباحثة

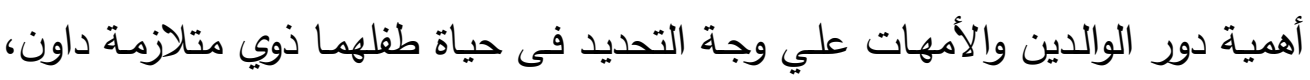

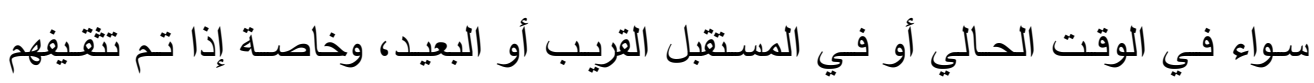

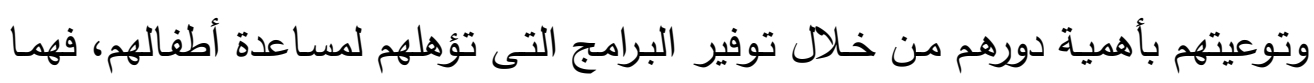

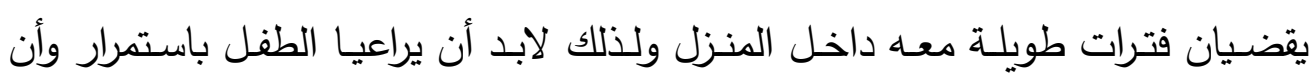
يشركا أخوته فى نثاطاته وأن يزيدوا من ساعات العمل معه لأن هذا يعطى لئى نتائج جيدة

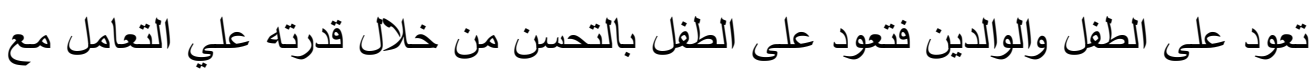

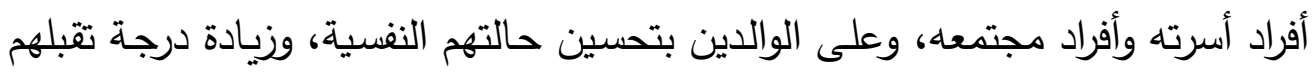

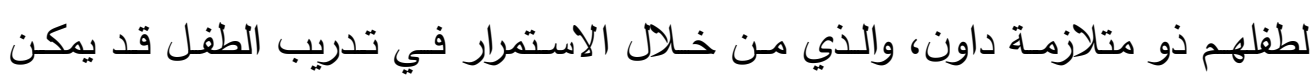
الوصول به إلي الإقتراب من الأسوياء.

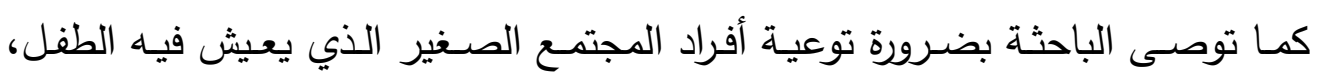

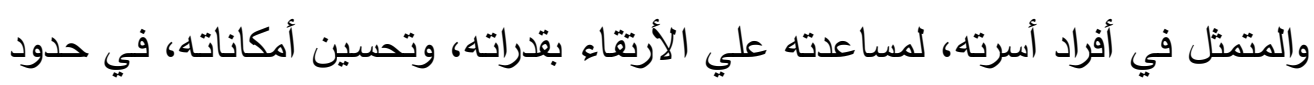
المتاح، ووفقاً لظروفة الخاصة. حتي لايصبح فريسة سهلة لأصحاب الضمائر الغائبه.

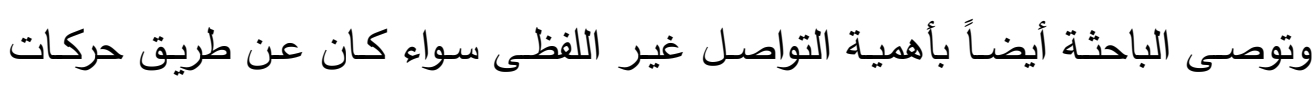

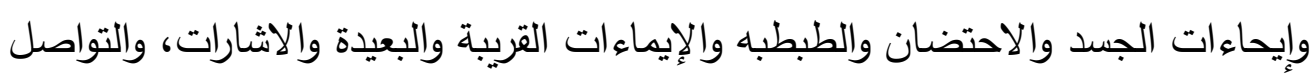

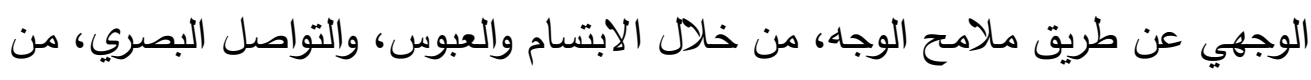

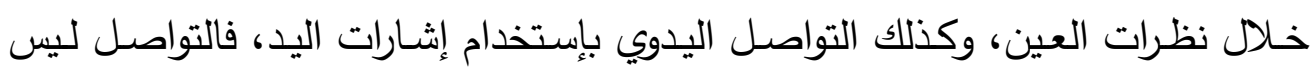
لفظياً فقط، فعلي الوالدين أن يدركا أهمية التواصل غير اللفظى فى حياة أطفالهم ذوي

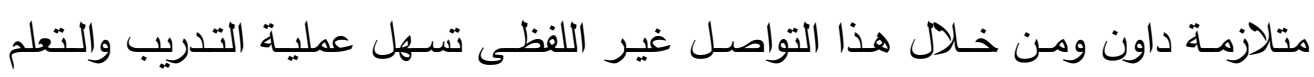
لعبارات ومفردات لفظية جديدة. وأخيراً توصى الباحثة بأهية استمرار الوالدين في تدريب أطفالهم ذوي متلازمة داون

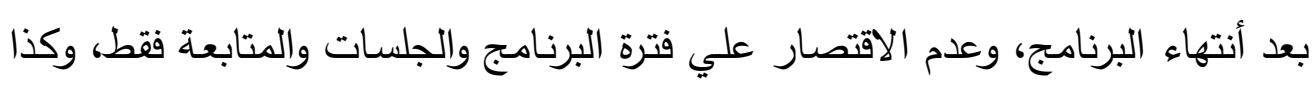

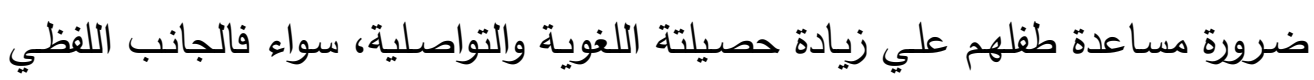
أو غير اللفظي، وعدم الاقتصار علي تدريب الطفل علي ما تلقاه من خلال البرنامج. 


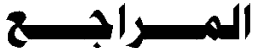

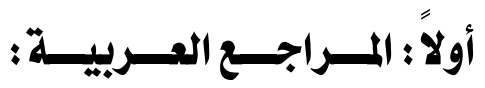

1- كمال إبراهيم مرسى (999 99 1): مرجع فى علم التخلف العقلى، طب، القاهرة، دار الجامعات.

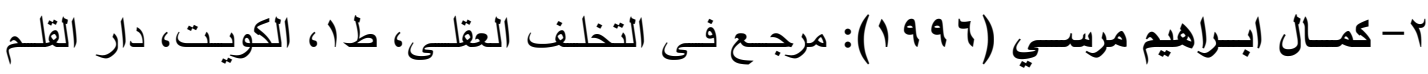
للنشر والتوزيع. r- أسماء عبدالله العطية (11 + ץ): تتمية بعض مهارات السلوك التكيفى لدى الأطفال من ذوى الإعاقة العقلية، طا، الأسكندرية، مؤسسة حورس الدولية للنشر والتوزيع.

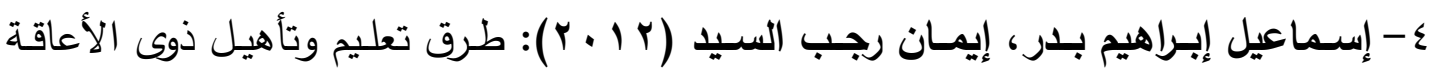

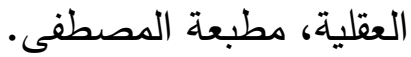
0- إسماعيل إبراهيم بدر( • ( ؟ ): مقدمة فى التربية الخاصة، الرياض، دار الزهراء للنشر والتوزيع. צ- إسماعيل إبراهيم بدر(11 + r): علم وظائف الأعضاء لذوى الاحتياجات الخاصـة، طا، الرياض، دار الزهراء للنشر والتوزيع. V- أثــرف أحمـد عبـد القـادر ( التلاميذ_ على تحصيلهم الدراسى، بحث منشور، كلية التربيه، جامعة بنها. 1- أشرف أحمد عبد القادر (؟ . . ץ): سيكولوجية التفوق والتخلف العقلي، طا، بنها، مؤسسة

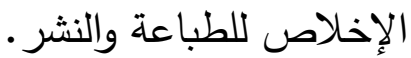
9- آمـال عبد السميع باظـة (ץ + . ץ): اضطرابات التواصل وعلاجها، طا، كلية التربية جامعة كفر الثيخ.

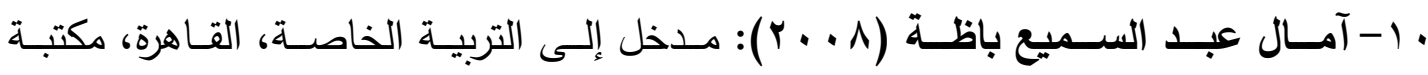

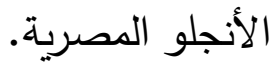

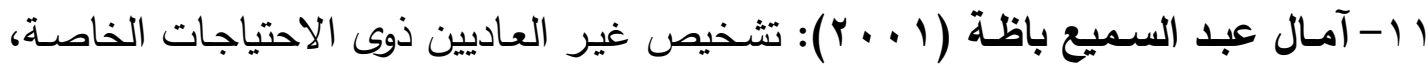
طا، جامعة طنطا، كلية التربية، كفر الثيخ. 


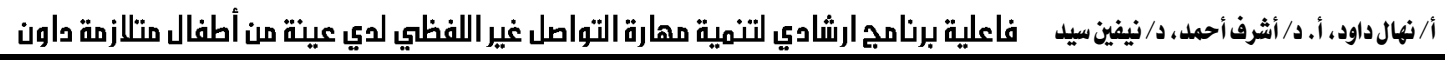

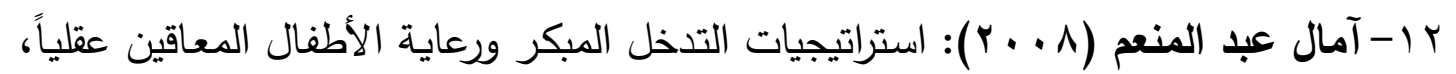

$$
\text { طا ، القاهرة، مكتبة زهراء الشرق. }
$$

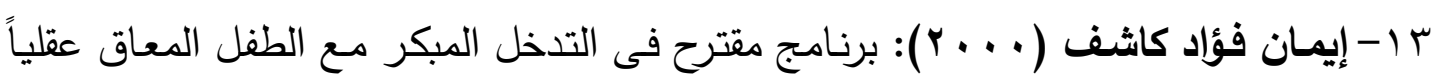
وأسـرته، المؤتمر الدولى الأول، كليـة التربيـة، جامعـة الزقازيق، دور كليـات التربيـة فى

$$
\text { التتمية البشرية فى الألفية الثالثة (OY - Y Y Y أبريل)، المجلد الأول. }
$$

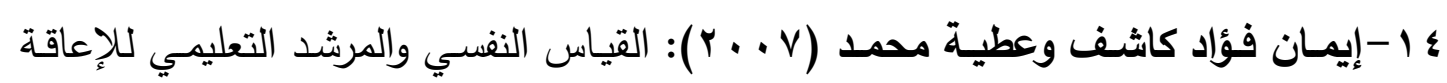

$$
\text { السمعية (اكتثاف وتعليم المعوقين)، القاهرة، دار الكتاب الحديث. }
$$

1 1-بورتاج مصر (999 (19): برنامج التتمية الثاملة للطفولة المبكرة (بورتاج)، قطاع الكتب،

$$
\text { وزارة التربية والتعليم. }
$$

7 ا -لـويس كامل مليكه (919 (1) ): الإعاقات العقلية والإضطرابات الإرتقائية، طا، القاهرة،

$$
\text { مكتبة الأنجلو المصرية. }
$$

V V الويس كامل مليكه (1991 (19): تعديل سلوك المعاق عقلياً "دليل الوالدين والمعلم"، القاهرة،

$$
\text { مكتبة النهضة العربية. }
$$

1 1- ليلى كرم الدين (09 9 ( )): نموذج لبرنامج للتنمية العقلية واللغوية للأطفال المتخلفين عقليا القابلين للتعلم بمدارس التربيـة الفكرية، القاهرة، المؤتمر القومى الأول للتربية الخاصـة، وزارة التربية والتعليم.

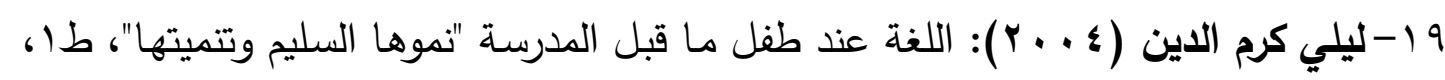

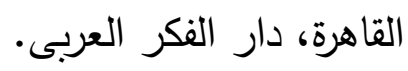

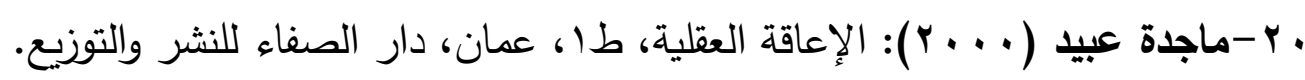


ا ب-المجموعة الإستشارية لنظم المعلومـات والإدارة (I-s-m) بالقاهرة بتصريح من مؤسسة

داون سندروم بلندن ( ( + ץ): سلسلة نحو غد مشرق لأولادنا ذوى الاحتياجات الخاصة

- لست وحدى فى هذا العالم - كيف نساعد أولادنا حاملى متلازمة داون - الجزء الرابع

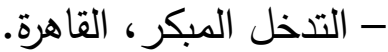

Y Y ب المجموعة الإستشارية لنظم المعلومـات والإدارة (I-S-m) بتصريح من مؤسسـة داون سندروم بلندن ( ( + †): سلسلة نحو غد مشرق لأولادنا ذوى الاحتياجات الخاصة - لست وحدى فى هذا العالم - كيف نساعد أولادنا حاملى متلازمة داون - الجزء الأول - التخاطب والسمع والكلام، القاهرة.

بץ-محمد ابراهيم عبد الحميد (999 19)): تعليم الأنثطة والمهارات لدى الأطفال المعاقين عقلياً، طا، القاهزة، دار الفكر العربى.

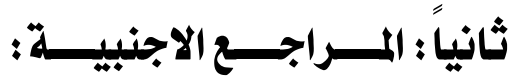

1- Iverson, J, Longs bardi, E \& Caselli, M. (2003): Relationship between gestures and words in children with Down's syndrome an typically developing children in the early stages of communicative development.

2- Roberts, J, Price, J \& Malkin, C, (2007): Language and Communication Development Indownsyndrome.

3- Mahoney, G, Perales, F, Wiggers, B \& Herman, B, (2006): Down syndrome and other disabilities.

4- Kumin, L, MD, B \& House, W, (2013): Early Communication Skills for Children With Down Syndrome: A Guide for Parents and Professionals.

5- Bassed on estimates by National National Institute Of Child Health \& Human Development "Down Syndrome Rates" (2015)

6- May, Miller Patrick (1999): introduction in non verbal communication, Nationals Deaf Education center, Gallaudet University. 
أ / نهال داود، أ. د/ أشرف أحمد، د/ نيفين سيد فاعلية برنامج ارشادي لتنهية مهارة التواصل غير اللفظي لدي عينة من أطفال متلاز زمة داون

7- Maloney, m, p, \& Michael, p. w, (1976): psychological Assessment, new York.

8- www.ed-uni.net.

9- Abell, R - l (1972): Essential psychology, Harper, N .Y.

10- Couteur Ann LE (2003): Autistic spectrum Disorders Practical Strategies for Teachers and Other Professionals, Northumberland County Council Communication Support Service, publishers Dvid Fulton. 